\title{
CORROSION BEHAVIOR OF MATERIALS AL5083 ALLOY, 316L STAINLESS STEEL AND A681 CARBON STEEL IN SEAWATER
}

\author{
Gina Genoveva ISTRATE, Alina Crina MUREȘAN \\ "Dunărea de Jos" University of Galaţi, Romania \\ e-mail: gina.istrate@ugal.ro
}

\begin{abstract}
In this paper the corrosion behavior of different materials has been evaluated based on exposure in seawater. The laboratory immersion test technique has been applied to evaluate the effect of seawater on the corrosion behavior of different materials. In three sets of experiments, carbon steels (A681 Type O7), austenitic stainless steels (316L) and aluminium alloys (Al5083) were utilized. The specimens were fixed fully submerged in seawater. The corrosion process was evaluated using weight loss method, open-circuit potential measurements (OCP) and polarization techniques. To determine gravimetric index and the rate of penetration, samples were immersed in corrosive environment for 89 days and weighed periodically. The electrochemical experiments were conducted with a Potentiostat/Galvanostat (PGP 201) analyzer. It was connected to a PC. The Voltamaster software was used for electrochemical data analysis. A three-electrode cell composed of a specimen as a working electrode, Pt as counter electrode, and saturated calomel electrode (SCE) $\left(\mathrm{Hg}(\mathrm{l}) / \mathrm{Hg}_{2} \mathrm{Cl}_{2}(\mathrm{~s})\right)$ as a reference electrode were used for the tests. The weight loss tests revealed the lowest corrosion rate values for stainless steel and aluminium alloys, indicating a beneficial use for these materials in marine environments. The potentiodynamic method shows that the lowest corrosion rate in seawater $(2.8 \mu \mathrm{m}$ year) was obtained for the Al5083 alloy, and the highest value of the corrosion rate (41.67 $\mu \mathrm{m} /$ year) for A681 carbon steel.
\end{abstract}

KEYWORDS: corrosion, weight loss, seawater, corrosion rate

\section{Introduction}

Corrosion represents the deterioration in time of metals, alloys, and also of materials in general, that are exposed to the action of some factors which are in the surrounding environment by chemical and electrochemical reactions.

The problem of corrosion is very important. In order to control this effect, certain methods of control or reduction of damages are needed, resulted after this process. Simultaneously, these methods are additional reasons for the maintenance of equipment.

Corrosion is a process that cannot be avoided and that causes damages to the industry and implicitly affects the world economy. For this reason, measures for preventing and slowing down the corrosion of equipment and metal parts had to be taken [1].

Seawater is the only electrolyte that contains a relatively high concentration of salts that usually occurs in nature, covering at the same time two-thirds of Earth's surface.
Metallic corrosion in the marine environment has been studied since the beginning of the century. Due to the high dissolved oxygen content in seawater, the corrosion mechanism of different metals is that of oxygen depolarization (except $\mathrm{Mg}$ and its alloys). In the Black Sea, the water can have a high content of hydrogen sulphide with the approximately total absence of dissolved oxygen. Due to the increase of acidity, the corrosion effect can take place due to the hydrogen depolarization, the cathodic overvoltage of the hydrogen release decreases, and the anodic depolarization increases due to the formation of sulphides on the metal surface [2-7].

After some studies, Vermeșan discovered that salinity, the biological component, and the seas and oceans' temperature are variables, as well as the corrosion rates are different in these waters. In warm seas, where under normal conditions the corrosion rate increases with the temperature, the deposition reaction of calcareous layers on metal surfaces is accelerated and these layers prevent corrosion. The alloy's nature is very important because it influences 
the corrosion effect. That is why alloys that have high $\mathrm{Cu}$ content cannot be covered by marine organisms due to the copper's toxicity [8].

In the naval industry, a series of materials with various characteristics necessary to develop a quality product is used to manufacture ships.

Different destructive attack forms can appear in structures, ships, and equipment that are exploited. Marine corrosion describes most of the problems that appear in contact with seawater. But not only, it also contains the way how corrosion evolves as a result of metal exposure to the atmospheric action or to salt corrosion in naval engines that operate with open cooling systems [9-11].

In this paper, the corrosion behaviour of some materials i.e., the A15083 alloy, 316L stainless steel, and A681 (type 07) carbon steel, was studied in seawater (Black Sea), and also their level of resistance to factors met in the corrosive environment.

\section{Materials and methods}

The tested samples were purchased from the DAMEN Shipyards Galati, one of the 32 biggest shipyards of the Damen Shipyards Group, repair sites and related companies around the world.

These materials, the Al5083 alloy, the $316 \mathrm{~L}$ stainless steel, and the A681 (type O7) carbon steel are used to manufacture various products: coastal ships, patrol ships, cargo ships, and logistic support ships, ferries, and barges.

The Al5083 alloy, the $316 \mathrm{~L}$ stainless steel, and the A681 (type 07) carbon steel were selected for constructing products for the naval industry, and not only, due to certain characteristics that make them resistant to corrosion up to a certain level.

The applied methods in studying the corrosion of metals must fulfil the conditions of detailed control of the factors that characterize the corrosion effect. Choosing the study methods firstly depends on the type of corrosion process which must be assessed, the purpose pursued, and the place where it is determined. Most of the time, more methods, quantitative and qualitative, are used simultaneously.

In this case, for the study of corrosion behaviour of the A15083 alloy, 316L stainless steel, and O7 carbon steel materials quantitative study methods were used. The quantitative methods of corrosion assessment are classified as follows:

- gravimetric methods;

- electrochemical methods.

The gravimetric methods are the most used in studying general corrosion (uniform or non-uniform) of metals, applying for electrolyte solutions and for non-polar organic substances.

These methods also have disadvantages which consist of high consumption of metal, errors after weighing, and the pickling that is done on the metal, long period of determination, and the fact that it is not applied to the forms of localized corrosion (pitting, intergrain) where the metal loss and the consumed oxygen quantity are very low $[12,13]$.

The gravimetric index or the corrosion rate $\left(\mathrm{V}_{\text {cor }}\right)$, indicated by $\mathrm{g} / \mathrm{m}^{2} \cdot \mathrm{h}$ or by $\mathrm{mg} / \mathrm{dm}^{2}$.day represent the weight variation of the metal sample $(\Delta \mathrm{m})$ as a result of corrosion, in the time unit $(\mathrm{t})$ and on the surface unit $(\mathrm{S})$, being demonstrated by the ratio:

$$
V_{\text {cor }}=\frac{\Delta m}{s \cdot t} \quad\left[\mathrm{~g} / \mathrm{m}^{2} \cdot \mathrm{h}\right]
$$

The penetration index $(\mathrm{P})$ indicates the average depth of the penetration of the corrosive environment in the metal mass. In other words, the average decreases in the thickness of the exposed sample (d) in the unit of time $(\mathrm{t})$, being defined by the ratio:

$$
P=\frac{d}{t} \quad[\mathrm{~mm} / \text { year }]
$$

The penetration index can be measured with a corrosion resistance conventional scale for materials (Table 1) which provides indicative information on the opportunity to use an alloy or metal as construction material for a corrosive environment.

Table 1. Corrosion resistance conventional scale for materials [14]

\begin{tabular}{|l|c|c|}
\hline Corrosion resistance group & The penetration index [mm/year] & Stability coefficient \\
\hline Perfectly stable & $<0.001$ & 1 \\
\hline \multirow{2}{*}{ Very stable } & $0.001-0.005$ & 2 \\
& $0.005-0.01$ & 3 \\
\hline \multirow{2}{*}{ Stable } & $0.01-0.05$ & 4 \\
& $0.05-0.1$ & 5 \\
\hline \multirow{2}{*}{ Relatively stable } & $0.1-0.5$ & 6 \\
& $0.5-1.0$ & 7 \\
\hline \multirow{2}{*}{ Less stable } & $1.0-5.0$ & 9 \\
\hline Unstable & $5.0-10$ & 10 \\
\hline
\end{tabular}


For determining the corrosion rate by gravimetric method, the seawater (Black Sea) was chosen as testing environments.

The tested materials were the A15083 aluminium alloy, the $\mathrm{O} 7$ carbon steel, and the $316 \mathrm{~L}$ stainless steel.

Before determining the corrosion rate of the materials, the samples were measured, cleaned, and prepared with metallographic paper, weighted with the help of an electronic balance, and then submerged in solution (seawater).

The most frequent polarization methods used in the laboratory for corrosion tests are: potentiodynamic polarization, potentiostatic polarization, and cyclic voltammetry. These techniques can provide important data regarding the corrosion mechanism, corrosion rate, and susceptibility to corrosion of specific materials in the environment. The polarization methods imply changing the working electrode potential and monitoring the current obtained as a function of time or potential.

The potentiodynamic method consists of varying the electrode potential at a determined speed by applying a direct current to the electrode. It is one of the most used polarization methods for determining corrosion resistance and is used for a wide range of analyses.

The corrosion current in the potentiodynamic charts can be calculated with the Stern-Geary formula which expresses the dependence between the polarization resistance and the corrosion current:

The value of the corrosion rate was calculated with the relation:

$$
V_{\text {cor }}=\frac{i_{\text {cor }} \cdot A \cdot 10}{D \cdot v \cdot 96500}
$$

where:

$\mathrm{i}_{\text {cor }}$ - the density of the corrosion current calculated with the Stern-Geary formula;

A - atomic mass of the metal;

D - metal density;

$\mathrm{v}$ - valence of the metal.

The specialized literature presents references to the behaviour of metallic materials used in the naval industry in seawater (natural or artificial) [15-17].

The corrosion tests were done using VOLTAMASTER 4 (PGP 201) connected to the electrochemical cell with three electrodes: the working electrode (W.E.), the tested sample on whose surface the measurement was done, the counter electrode (C.E.), the platinum electrode and calomel electrode $\mathrm{SCE}\left(\mathrm{Hg}(\mathrm{l}) / \mathrm{Hg}_{2} \mathrm{Cl}_{2}\right.$ (s), $\mathrm{KCl}$, sol sat) as the reference electrode (R.E.; $\mathrm{E} \mathrm{Hg} / \mathrm{Hg}_{2} \mathrm{Cl}_{2}=+0.2444 \mathrm{~V}$ at $\left.25{ }^{\circ} \mathrm{C} / \mathrm{ESH}\right)$. The system was connected to a computer with data analysis software. The analysed samples (the working electrode) have been isolated on one side before being immersed in the seawater testing solution.

The corrosion tests of each sample began with the monitoring of the open circuit potential - OCP, after submerging the samples in the testing solution until it reached the stationary value.

For the potentiodynamic polarization tests, the following parameters were used: initial potential (I.P.) $-1.0 \mathrm{~V}$ (SCE), final potential (F.P.) $+300 \mathrm{mV}$ (SCE), scanning speed $2 \mathrm{mV} / \mathrm{s}$.

\section{Results and discussions}

\subsection{Results obtained by gravimetric methods}

Determining the corrosion rate after 7 days since immersion: After a 7-day period from immersion of the samples in the seawater, they were cleaned, weighted, and submerged again. The masses of the samples both initial and at 7 days are shown in Table 2.

Table 2. Weight variation at 7 days

\begin{tabular}{|c|c|c|}
\hline Materials & $\begin{array}{c}\text { Initial } \\
\text { weight }(\mathbf{g})\end{array}$ & $\begin{array}{c}\text { Weight after 7 } \\
\text { days }(\mathbf{g})\end{array}$ \\
\hline $\begin{array}{c}\text { Al5083 } \\
\text { aluminium } \\
\text { alloy }\end{array}$ & 7.4395 & 7.4299 \\
\hline $\begin{array}{c}\text { 316L stainless } \\
\text { steel }\end{array}$ & 19.6243 & 19.6187 \\
\hline $\begin{array}{c}\text { A681 carbon } \\
\text { steel }\end{array}$ & 20.1641 & 20.1429 \\
\hline
\end{tabular}

The values of the corrosion rate were calculated with the ratio (1), after submerging the samples in seawater for 7 days.

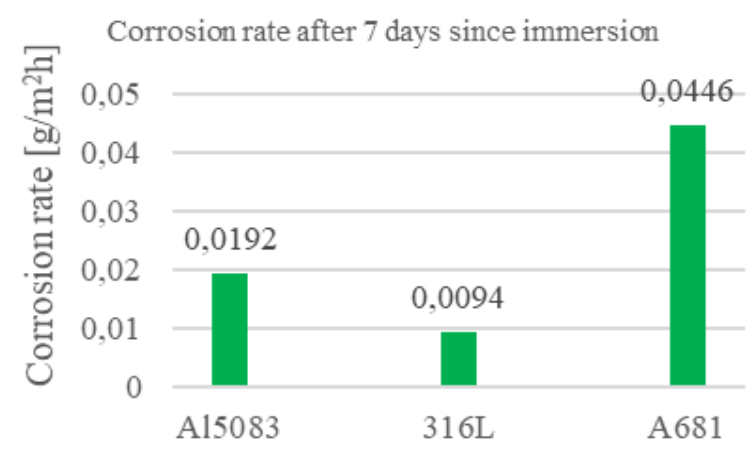

Fig. 1. The corrosion rate after submerging in seawater for 7 days 
According to the data from Figure 1, it can be seen that after 7 days of immersion in seawater, the corrosion rate has the highest value in the case of the O7 carbon steel, $0.0446 \mathrm{~g} / \mathrm{m}^{2} \mathrm{~h}$. Lower values were obtained for the other materials, such as a value of 2.3 times lower was calculated in the case of the Al 5038 aluminium alloy i.e., $0.0192 \mathrm{~g} / \mathrm{m}^{2} \mathrm{~h}$. The lowest value for the corrosion rate at 7 days of immersion was calculated for the $316 \mathrm{~L}$ stainless steel $\left(0.0094 \mathrm{~g} / \mathrm{m}^{2} \mathrm{~h}\right)$, a value 4.7 times lower than that calculated for the A681 (type O7) carbon steel.

Determining the corrosion rate after 28 days since immersion: The variation of the masses of the samples tested in seawater after 28 days of immersion is presented in Table 3 and the corrosion rate for each tested material is presented in Figure 2.

Table 3. Weight variation at 28 days

\begin{tabular}{|c|c|c|}
\hline Materials & $\begin{array}{c}\text { Initial } \\
\text { weight }(\mathbf{g})\end{array}$ & $\begin{array}{c}\text { Weight } \\
\text { after 28 } \\
\text { days (g) }\end{array}$ \\
\hline $\begin{array}{c}\text { Al5083 } \\
\text { aluminium } \\
\text { alloy }\end{array}$ & 7.4395 & 7.4216 \\
\hline $\begin{array}{c}\text { 316L } \\
\text { stainless } \\
\text { steel }\end{array}$ & 19.6243 & 19.6106 \\
\hline $\begin{array}{c}\text { A681 (O7) } \\
\text { carbon steel }\end{array}$ & 20.1641 & 20.1165 \\
\hline
\end{tabular}

The corrosion rate for the three tested materials A15038, 316L, and A681 (O7) have the same rate in the chart comparatively presented with that from the 7 and 14 days since immersion.

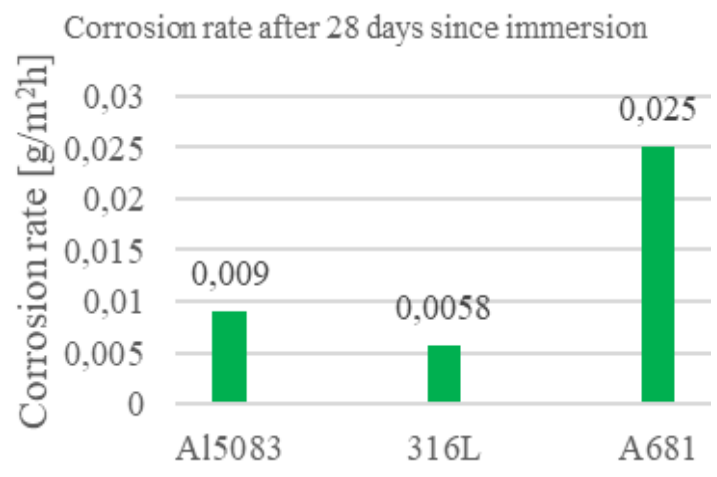

Fig. 2. The corrosion rate after submerging in seawater for 28 days

According to the data from Figure 2, it can be observed that after 28 days of immersion in seawater the corrosion rate has the highest value in the case of the $\mathrm{O} 7$ carbon steel $\left(0.025 \mathrm{~g} / \mathrm{m}^{2} \mathrm{~h}\right)$. Lower values were obtained for the other materials, like a value of 2.7 times lower for the Al 5038 aluminium alloy i.e., $0.009 \mathrm{~g} / \mathrm{m}^{2} \mathrm{~h}$. The lowest value for the corrosion rate after 7 days of immersion was calculated for the $316 \mathrm{~L}$ stainless steel $\left(0.0058 \mathrm{~g} / \mathrm{m}^{2} \mathrm{~h}\right)$, a value 4.3 times lower than that calculated for the carbon steel.

Determining the corrosion rate after 89 days since immersion: The variation of the masses of the samples tested in seawater after 89 days of immersion is presented in Table 4. and the corrosion rate for each tested material is presented in Figure 3.

Table 4. Weight variation at 89 days

\begin{tabular}{|c|c|c|}
\hline Materials & $\begin{array}{c}\text { Initial } \\
\text { weight (g) }\end{array}$ & $\begin{array}{c}\text { Weight } \\
\text { after 89 } \\
\text { days (g) }\end{array}$ \\
\hline $\begin{array}{c}\text { Al5083 } \\
\text { aluminium } \\
\text { alloy }\end{array}$ & 7.4395 & 7.4216 \\
\hline $\begin{array}{c}\text { 316L } \\
\text { stainless } \\
\text { steel }\end{array}$ & 19.6243 & 19.6106 \\
\hline $\begin{array}{c}\text { A681 (O7) } \\
\text { carbon steel }\end{array}$ & 20.1641 & 20.1165 \\
\hline
\end{tabular}

The corrosion rate for the three tested materials $\mathrm{Al} 5038,316 \mathrm{~L}$, and $\mathrm{A} 681$ (O7) have the same rate in the chart comparatively presented with that from the 7 and 28 days since immersion.

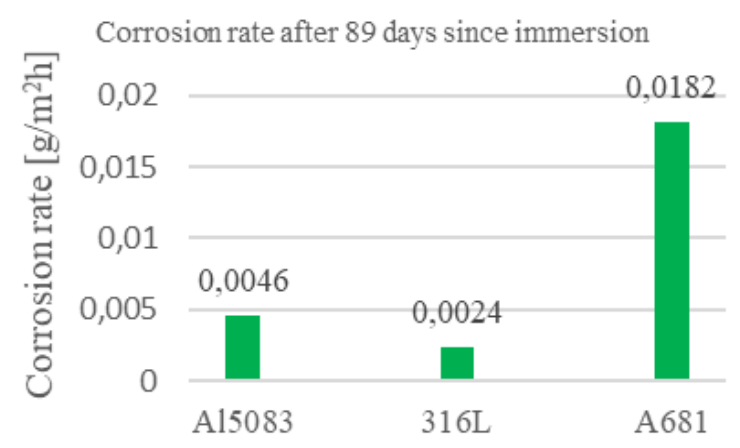

Fig. 3. The corrosion rate after submerging in seawater for 89 days

According to the data from figure 3, it can be observed that after 89 days of immersion in seawater the corrosion rate has the highest value in the case of the 07 carbon steel $\left(0.0182 \mathrm{~g} / \mathrm{m}^{2} \mathrm{~h}\right)$. Lower values were obtained for the other materials, like a value of 3.9 times lower for the Al5038 aluminium alloy i.e., $0.0046 \mathrm{~g} / \mathrm{m}^{2} \mathrm{~h}$. The lowest value for the corrosion rate after 7 days of immersion was calculated for the $316 \mathrm{~L}$ stainless steel $\left(0.0024 \mathrm{~g} / \mathrm{m}^{2} \mathrm{~h}\right)$ a value 7.5 times lower than that calculated for the $\mathrm{O} 7$ carbon steel. 


\section{THE ANNALS OF “DUNAREA DE JOS” UNIVERSITY OF GALATI \\ FASCICLE IX. METALLURGY AND MATERIALS SCIENCE \\ Nº 2 - 2021, ISSN 2668-4748; e-ISSN 2668-4756 \\ Article DOI: $\underline{\text { https://doi.org/10.35219/mms.2021.2.07 }}$}

Micrographs were done with the help of an optical microscope to which a USB digital microscopy camera type OPTIKAM 4083.B1 was attached.

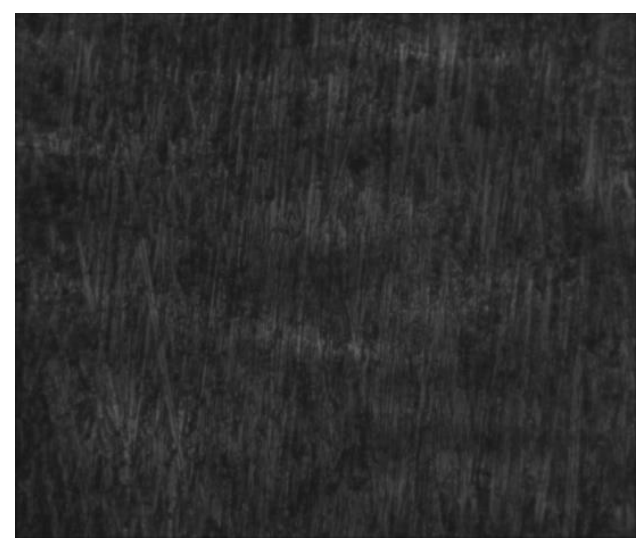

In Figures 4-6, micrographs for the Al5038, 316L, and A681 (O7) materials are presented, before and after immersion for 89 days in seawater.

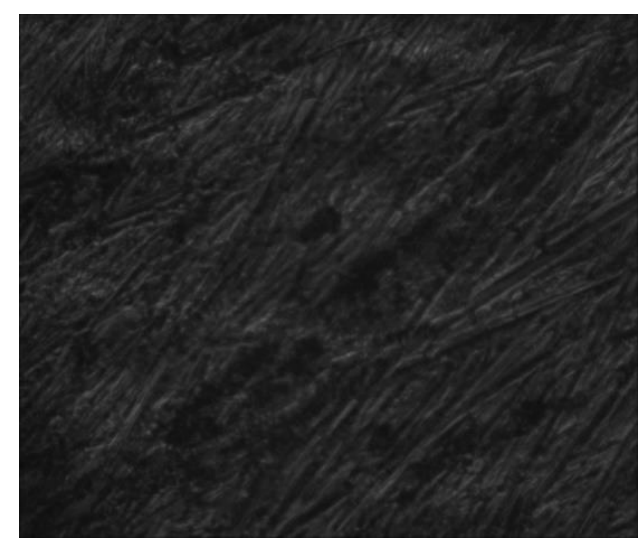

b

Fig. 4. Micrographs of Al 5083 alloy in the initial phase (a) and 89 days after immersion (b)

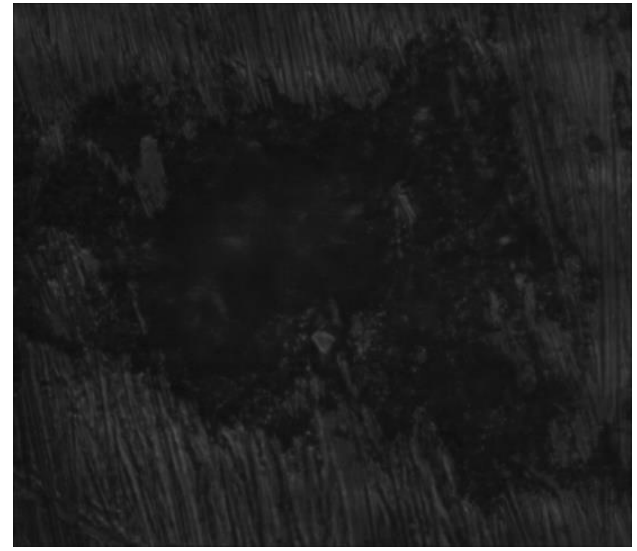

a

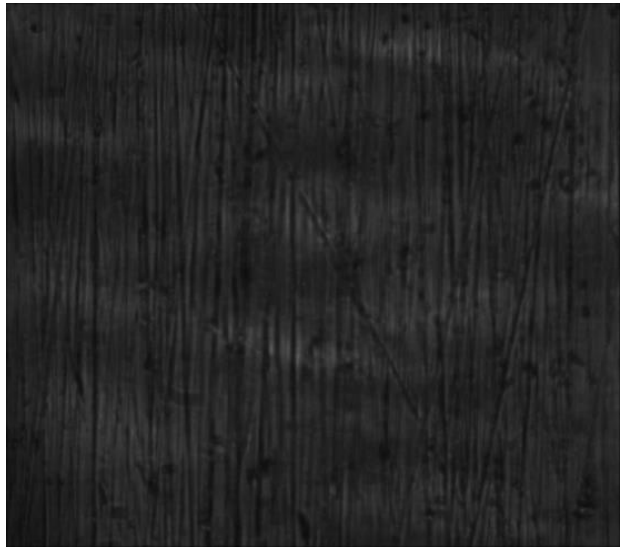

$\mathrm{b}$

Fig. 5. Micrographs of $316 L$ stainless steel in the initial phase (a) and 89 days after immersion (b)

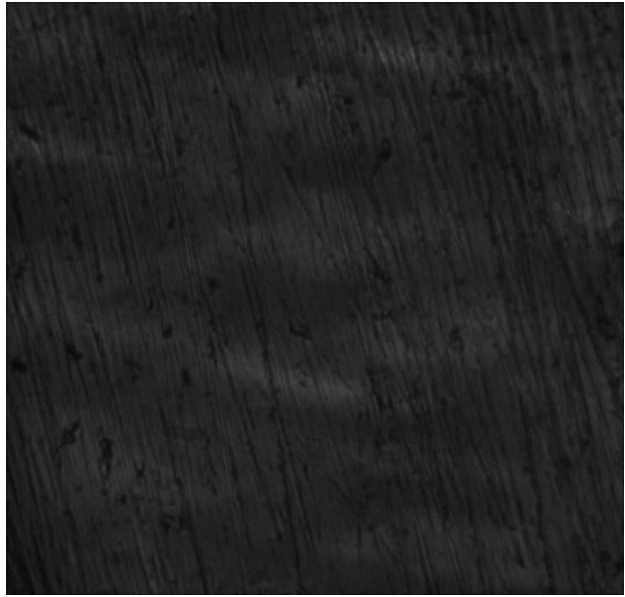

a

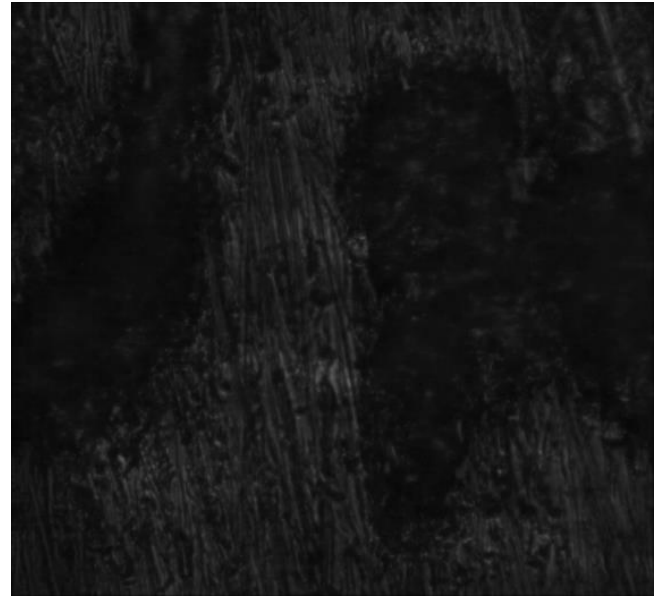

b

Fig. 6. Micrographs of A681 type 07 carbon steel in initial phase (a) and 89 days after immersion (b) 
It can be observed that a degradation process of the initial surface after the interaction with the seawater appears.

The corrosion that was gravimetrically discovered in the seawater was highlighted by metallographic analyses on the surfaces of the A15083, 316L, and A681 (O7) materials subjected to corrosion for 89 days. The induced modifications by various corrosion mechanisms to the corrosion material/environment interface were studied by relating to the witness samples (before corrosion). After the 89 days of immersion, the morphology of the samples' surfaces is deeply modified. It is found that the degradation mechanisms of materials due to corrosion are complex. Thus, it can be noticed that the localized corrosion highlighted by corrosion spots - relatively big and small depth portions in the case of the stainless steel, corrosion plates - relatively small but deep surfaces in the case of the carbon steel, and pitting concentrated on small surfaces (with diameters to $100 \mu \mathrm{m}$ ) in the case of aluminium alloy.

Determining the penetration index after 7 days since immersion: Figure 7. represents the penetration index $\mathrm{P}$ for the tested materials after being immersed in seawater for 7 days.

\section{Penetration index after 7 days since immersion}

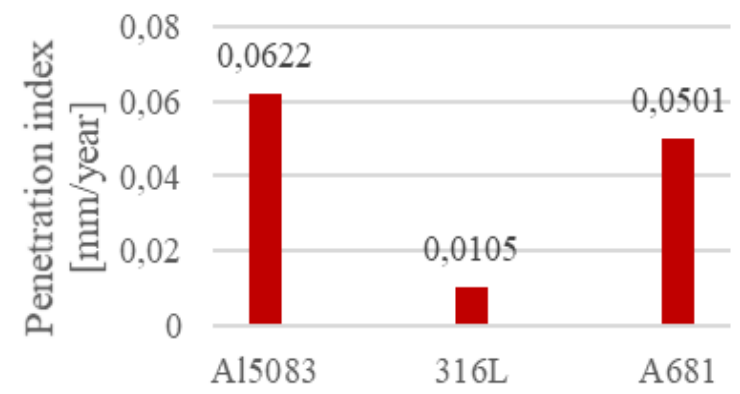

Fig. 7. Penetration index calculated after 7 days since immersion

After 7 days of immersion in seawater and after the calculations were done, the highest penetration index was obtained for the Al 5038 aluminium alloy with a value of $0.0622 \mathrm{~mm} /$ year. According to Table 1 , the Al5038 alloy presents the stability ratio of 5 in the marine environment, which is group III of resistance i.e., stable.

The lowest penetration index was obtained by the $316 \mathrm{~L}$ stainless steel with a value of 0.0105 $\mathrm{mm} /$ year which is also in group III of resistance, meaning that is stable, well usable.

The 07 carbon steel had a close value of the penetration index to that of the aluminium alloy i.e., $0.0501 \mathrm{~mm} /$ year, thus proving that the carbon steel also presents the stability ratio of 5 in the marine environment, which is group III of resistance i.e., stable.

Determining the penetration index after 89 days since immersion: Figure 8. represents the penetration index $\mathrm{P}$ for the tested materials after being immersed in seawater for 89 days.

Penetration index after 89 days since immersion

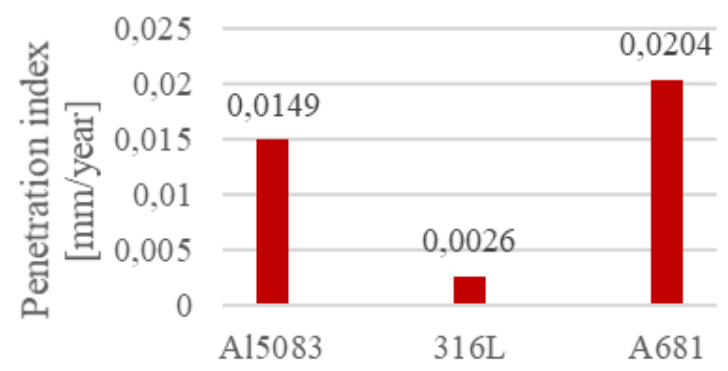

Fig. 8. Penetration index calculated after 89 days since immersion

After 89 days of immersion in seawater and after the calculations were done, the highest penetration index was obtained for the $\mathrm{O} 7$ carbon steel with a value of $0.0204 \mathrm{~mm} /$ year. According to Table 1, the $\mathrm{O} 7$ carbon steel presents the stability ratio of 4 in the marine environment, which is group III of resistance that is stable after 89 days since immersion.

The lowest penetration index was obtained by the $316 \mathrm{~L}$ stainless steel with a value of 0.0026 $\mathrm{mm} /$ year, resulting in a stability ratio of 2 , which is group II of resistance, that is very stable.

The Al5038 aluminium alloy had a penetration index value of $0.0149 \mathrm{~mm} /$ year, this demonstrating that the carbon steel presents the stability ratio of 4 in the marine environment, which is group III of resistance, that is stable.

\subsection{Results obtained by the electrochemical method}

Tracing and interpreting the Tafel curves give information about the corrosion current's intensity, polarization resistance, and the corrosion rate for the tested systems. The corrosion rate values were calculated with the ratio (3).

The open circuit potential of the $316 \mathrm{~L}$ stainless steel inclines towards more positive values, suggesting a better corrosion behaviour in the seawater. The open circuit potential for the A15038 alloy starts from the most negative potential (-670) and increases linear, passing the open circuit potential for the carbon steel.

The potentiodynamic charts for the Al5038 alloy, 07 steel, and $316 \mathrm{~L}$ steel in the seawater are 
presented in figure 10 and the corresponding values of the corrosion current, polarization resistance, and the calculated Tafel parameters are presented in Table 5 .

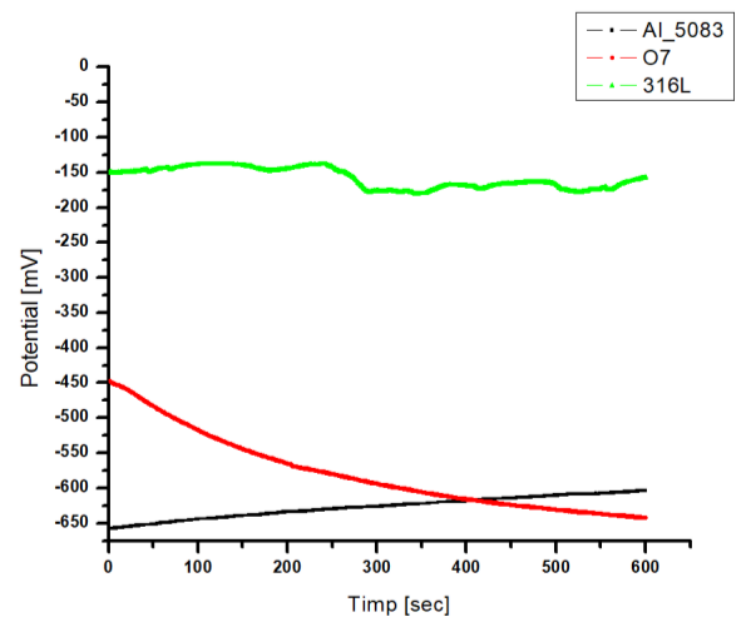

Fig. 9. Evolution of open circuit potential in the seawater testing solution

From the presented data, it can be observed that the corrosion potential inclines towards negative values for the $\mathrm{O} 7$ carbon steel.
For the tested materials, the lowest corrosion rate in seawater $(2.8 \mu \mathrm{m} /$ year $)$ was obtained for the Al5038 alloy and the highest value of the corrosion rate $(41.67 \mu \mathrm{m} /$ year) for the $\mathrm{O} 7$ carbon steel. For the stainless steel, a corrosion rate close to that of the aluminium alloy has been calculated i.e., $4.2 \mu \mathrm{m} /$ year.

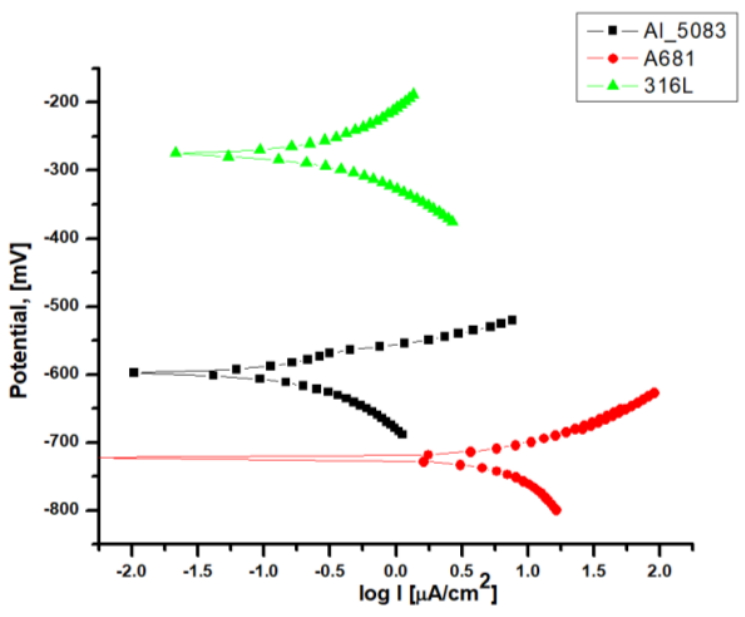

Fig. 10. Comparative potentiodynamic curves for Al5083 alloy, A681 type O7 carbon steel and 316 Ltainless steel in seawater

Table 5. Corrosion parameters determined from Tafel curves

\begin{tabular}{|c|c|c|c|c|c|c|}
\hline Materials & $\begin{array}{c}\text { Potential } \\
{[\mathbf{m V}]}\end{array}$ & $\begin{array}{c}\mathbf{R p} \\
{\left[\mathbf{k o h m} \mathbf{~ c m}^{2}\right]}\end{array}$ & $\begin{array}{c}\mathbf{i} \text { cor } \\
{\left[\boldsymbol{\mu} \mathbf{A} / \mathbf{c m}^{2}\right]}\end{array}$ & $\begin{array}{c}\boldsymbol{\beta a} \\
{[\mathbf{m V / d e c a d e}]}\end{array}$ & $\begin{array}{c}\boldsymbol{\beta c} \\
{[\mathbf{m V / d e c a d e}]}\end{array}$ & $\begin{array}{c}\mathbf{V} \text { cor } \\
{[\boldsymbol{\mu} \mathbf{m} / \mathbf{y e a r}]}\end{array}$ \\
\hline $\begin{array}{c}\text { A1 5083 aluminium } \\
\text { alloy }\end{array}$ & -598.2 & 76.70 & 0.2573 & 48.8 & 137.9 & 2.801 \\
\hline A681 carbon steel & -724.0 & 3.36 & 3.8484 & 60.4 & 107.2 & 41.670 \\
\hline 316L stainless steel & -275.6 & 61.97 & 0.3522 & 124.4 & 110.5 & 4.214 \\
\hline
\end{tabular}

\section{Conclusions}

On the entire research period of 89 days, it was observed how each material, the A15083 alloy, the 316L stainless steel, and the $\mathrm{O} 7$ carbon steel suffered modifications in terms of material density, but also at the materials' surface, these cracking at the surface.

After the studies were finished, which consisted of measuring the corrosion rate, the penetration index of the metals, and the corrosion potential, it was observed that of all materials the least resistant to seawater corrosion is the A681 (type O7) carbon steel, and the most resistant were the Al5038 alloy and the 316L stainless steel.

Marine corrosion can be prevented and the most important factors in preventing marine corrosion are: the project, material selection, cost criteria, manufacturing factors, purchasing criteria, elements of influence due to the construction system, and the mode of operation and maintenance.

\section{References}

[1]. Zaki Ahmad, Principles of Corrosion Engineering and Corrosion Control, ISBN: 0750659246, Elsevier Science \& Technology Books, 2006.

[2]. Féron D., Corrosion Behaviour and Protection of Copper and Aluminium Alloys in Seawater, Imprint Woodhead Publishing, ISBN 978-1-84569-241-4, 2017.

[3]. Abdolreza Mostafanejad, Mehdi Iranmanesh, Arman Zarebidaki, An experimental study on stress corrosion behavior of A131/A and A131/AH32 low carbon steels in simulated seawater, Ocean Engineering, vol. 188, 106204, 15 September 2019.

[4]. Xiang Wang, Robert E. Melchers, Corrosion of carbon steel in presence of mixed deposits under stagnant seawater conditions, Journal of Loss Prevention in the Process Industries, vol. 45, Pages 29-42, January 2017.

[5]. Takumi Kosaba, Izumi Muto, Yu Sugawara, Effect of anodizing on galvanic corrosion resistance of Al coupled to Fe or type 430 stainless steel in diluted synthetic seawater, Corrosion Science, vol. 179, 109145, February 2021. 


\section{THE ANNALS OF "DUNAREA DE JOS” UNIVERSITY OF GALATI \\ FASCICLE IX. METALLURGY AND MATERIALS SCIENCE \\ $\mathrm{N}^{\circ} .2$ - 2021, ISSN 2668-4748; e-ISSN 2668-4756 \\ Article DOI: https://doi.org/10.35219/mms.2021.2.07}

[6]. Yuanyuan Shen, Yaohua Dong, Yi Yang, Qinghong Li, Hongling Zhu, Wenting Zhang, Lihua Dong, Yansheng Yin, Study of pitting corrosion inhibition effect on aluminium alloy in seawater by biomineralized film, Bioelectrochemistry, vol. 132, 107408, April 2020.

[7]. Hosni Ezuber, El-Houd A., El-Shawesh F., A study on the corrosion behavior of aluminium alloys in seawater, Materials \& Design, vol. 29, iss. 4, Pages 801-805, 2008.

[8]. Horațiu Vermeșan, Coroziune și protecție anticorozivă, Editura Risoprint, Cluj-Napoca, 2005.

[9]. Shiqiang Chen, Dun Zhang, Corrosion behavior of Q235 carbon steel in air-saturated seawater containing Thalassospira sp., Corrosion Science, vol. 148, p. 71-82, 2019.

[10]. Baoping Cai, Yonghong Liu, Xiaojie Tian, Fei Wang, Hang Li, Renjie Ji, An experimental study of crevice corrosion behaviour of $316 \mathrm{~L}$ stainless steel in artificial seawater, Corrosion Science, vol. 52, iss. 10, p. 3235-3242, October 2010.

[11]. Kemal Nişancioĝlu, Corrosion Behaviour and Protection of Copper and Aluminium Alloys in Seawater, European Federation of Corrosion (EFC) Series, p. 145-155, 2007.

[12]. Jeenat Aslam, Ruby Aslam, Salhah Hamed Alrefaee, Mohammad Mobin, Afroz Aslam, Mehtab Parveen, Chaudhery Mustansar Hussain, Gravimetric, electrochemical, and morphological studies of an isoxazole derivative as corrosion inhibitor for mild steel in $1 \mathrm{M} \mathrm{HCl}$, Arabian Journal of Chemistry, vol. 13, iss. 11, p. 7744-7758, November 2020.

[13]. Kuangtsan Chiang, Todd Mintz, Gravimetric techniques, Techniques for Corrosion Monitoring (Second Edition), Woodhead Publishing Series in Metals and Surface Engineering, p. 239-254, 2021.

[14]. Teodora Badea, Mihai V. Popa, Maria Nicola, Știința și ingineria coroziunii, Editura Academiei Române, ISBN 973-270856-5, București, 2002.

[15]. Loto C. A., Fayomi O. S. I., Loto R. T., Popoola A. P. I., Potentiodynamic Polarization and Gravimetric Evaluation of Corrosion of Copper in $2 \mathrm{M} \mathrm{H}_{2} \mathrm{SO}_{4}$ and its inhibition with Ammonium Dichromate, Procedia Manufacturing, vol. 35, p. 413418, 2019.

[16]. Wei Wang, Peter E. Jenkins, Zhiyong Ren, Electrochemical corrosion of carbon steel exposed to biodiesel/simulated seawater mixture, Corrosion Science, vol. 57, p. 215-219, April 2012.

[17]. Xin S. S., Li M. C., Electrochemical corrosion characteristics of type $316 \mathrm{~L}$ stainless steel in hot concentrated seawater, Corrosion Science, vol. 81, p. 96-101, April 2014. 